\title{
THE IMPACT OF OUTDOOR PHYSICAL EDUCATION CLASSES, GENDER AND PLACE OF RESIDENCE ON PHYSICAL CAPACITY AND FITNESS OF PRIMARY SCHOOL CHILDREN
}

\section{WPŁYW TERENOWYCH LEKCJI WYCHOWANIA FIZYCZNEGO, PŁCI I MIEJSCA ZAMIESZKANIA NA WYDOLNOŚĆ I SPRAWNOŚĆ FIZYCZNĄ DZIECI SZKÓŁ PODSTAWOWYCH}

\author{
${ }^{1}$ Gdańsk University of Physical Education and Sport, Poland \\ ${ }^{2}$ Białystok University of Technology, Poland \\ ${ }^{3}$ Medical University of Lublin, Poland
}

\begin{abstract}
S u m mary
The search for new methods of increasing the efficiency of physical education school lessons is of great importance. The reason for it frequently confirmed in the literature, is a lack of increase of pupils' skills, both in physiological and mental area. Thus, we should highlight the need of pedagogical intervention on all stages of school education.

The aim of the study was to evaluate the influence of selected individual and environmental conditions, e.g. gender, area of exercises and places of residence on physical endurance and fitness of children in school age.

The research method was a natural experiment, the main assumption of which was to organize physical education lessons mostly outdoor during the period of two years of experiment duration. Research included 203 primary school children - 102 boys and 101 girls. The experimental group that conducted approximately $65 \%$ of lessons outdoor, included 86 pupils. The control group included 117 pupils

who exercised the same number of lessons usually indoor (in school rooms). 113 pupils came from urban areas and $90-$ from rural areas. To test physical abilities of children International Test of Physical Fitness and Cooper's test were used. We also determined Fitness Index and Index of Restitution Efficiency.

Lessons conducted outdoor positively influenced speed, jumping ability and endurance of children. The results of Index of Restitution Efficiency were improved and the increase of oxygen consumption was observed. Boys demonstrated better endurance and to lower extent better physical fitness as compared with girls. Place of residence was the factor of the lowest significance.

We confirmed the need of organizing physical education classes outdoor. Contact with nature has been shown to be an advisable form of human activity, especially in period of persistent ecological threads of health.
\end{abstract}

\section{Streszczenie}

Analiza nowych metod zwiększania efektywności lekcji wychowania fizycznego ma doniosłe znaczenie. Przyczyną tego jest wielokrotnie wzmiankowany w literaturze brak progresu umiejętności uczniów, zarówno na płaszczyźnie fizjologicznej jak i mentalnej. Dlatego wskazuje się na potrzebę interwencji pedagogicznych na wszystkich poziomach edukacji.

Celem badań była ocena wpływu wybranych indywidualnych i środowiskowych warunków takich jak płeć, miejsce ćwiczeń czy miejsce zamieszkania na wydolność i sprawność fizyczną dzieci w wieku szkolnym.

Metodą badawczą był eksperyment naturalny, którego głównym założeniem była organizacja lekcji wychowania fizycznego w terenie w czasie 2 lat trwania badań. Badaniami objęto 203 dzieci szkoły podstawowej - 102 chłopców i 101 dziewcząt. Grupa eksperymentalna realizująca $65 \%$ lekcji na 
otwartej przestrzeni, liczyła 86 uczniów. Grupa kontrolna w liczbie 117 uczniów realizowała taką samą liczbę lekcji w pomieszczeniach szkolnych. 113 uczniów pochodziło z obszarów miejskich, a $90-\mathrm{z}$ wiejskich. Do testowania sprawności i wydolności wykorzystano Międzynarodowy Test sprawności Fizycznej oraz test Coopera. Wyznaczono również indeks sprawności i wskaźnik skuteczności restytucji.

Lekcje organizowane $\mathrm{w}$ terenie otwartym wpłynęły pozytywnie na szybkość, skoczność i wytrzymałość dzieci.
Poprawie uległ wskaźnik skuteczności restytucji i zaobserwowano zwiększenie poboru tlenu. Chłopcy wykazali większą wytrzymałość i w nieco mniejszym stopniu także wyższy poziom sprawności fizycznej w porównaniu z dziewczętami. Czynnikiem o najmniejszym znaczeniu okazało się miejsce zamieszkania.

Należy potwierdzić potrzebę organizacji terenowych lekcji wychowania fizycznego. Kontakt z przyrodą wydaje się być wskazaną formą aktywności człowieka, szczególnie w dobie utrzymujących się ekologicznych zagrożeń zdrowia.

Key words: outdoor physical education, physical capacity, fitness, school children

Stowa kluczowe: terenowe lekcje wychowania fizycznego, wydolność fizyczna, sprawność fizyczna, dzieci w wieku szkolnym

\section{INTRODUCTION}

From many years one can observe direct relation between increased physical activity and physical fitness of organism. Fitness can be understood a strictly motoric aspect and, more generally, as functional abilities of an organism. Possibilities for assessment of activity proportioning and control of fitness in groups of children are connected with their participation in sports clubs or in school physical education classes. The second possibility allows researchers to have contact with higher number of children and allows them to carry out scientific experiments, rarely applied in this area. On the other hand, a need of searching for new methods of interaction between pupils and teacher in order to improve health of young generation still exists. This results from gradual limiting teenagers' contacts with physical activity in daily life, what effects in constraint of endurance and physical fitness. Besides of strengthening sedentary tendencies modern times assume excessive contact with products of civilization what leads to breaking human contact with surrounding natural environment. Considering this fact, a postulate of human's return to nature's bosom, and more active way of spending time within it often occurs $[1,2]$.

The aim of the study was to determine the degree of changes in the system's functional parameters of primary school children during 2-year classes of physical education conducted mostly as outdoor classes. Preliminary, we assumed that higher number of lessons in the contact with nature can stimulate physical development of pupils because of numerous natural elements, the shortage of which is observed in closed school area. Fresh air, contact with natural light, stimulating influence of wind and organic compounds from plants, as well as toughening influence of outdoor temperature changes can be recognized as elements that can increase positive effects of outdoor physical activity. Simultaneously, we made an attempt to evaluate the importance of gender and place of residence as factors shaping physical fitness.

\section{MATERIAL AND METHODS}

The project was conducted in the Pomeranian Voivodeship (Poland) between the years 2006 and 2008. Four schools from Pomeranian Voivodeship participated: there were 2 urban schools from Gdynia and 2 rural schools placed in Choczewo and Luzion. In each school 2 groups of boys (experimental and control) and 2 groups of girls (experimental and control) participated in the project. 203 pupils (101 girls and 102 boys) participated in the project throughout the whole period of its duration. Experimental group included 86 pupils and control group - 117 pupils. 113 pupils came from urban area and 90 from rural areas. Total 288 hours of physical education lessons were planned, but eventually the percentage of outdoor classes for experimental group reached $65 \%$ outdoor classes (187 hours) and 30\% for control classes ( 86 hours).

The main method applied in the study was a natural experiment. To evaluate prosomatic attitudes the following test were used:

1. International Fitness Test (IFT) - used to test general physical fitness and its specific components. IFT was conducted with the usage of stop-watches, measurement belts, dynamometers, flags, gymnastic bars, gymnastic blocks and benches with centimeter scale. A two-day test battery, consisted of the 50-meter sprint, standing long jump, grip strength, 600-meter run, 30-second sit-ups, pull-ups, 10-meter shuttle run, and trunk flexion. All results were expressed in points according to Drabik [3]. 
2. Cooper test - 12-minute steady pace run test allowing the evaluation of the level of endurance. The outcome is based on distance expressed in meters. Oxygen consumption was calculated indirectly using Cooper's and Howald's formulas [4]. Cooper's formula: $(33+0.17 *$ distance covered in meters - 133) anticipated progression of $0.7 \mathrm{ml}$ on each 50 meters of distance. Howald's formula (distance covered in meters $* 0.02-5.4$ ) anticipated progression of $1.0 \mathrm{ml}$ on each distance of 50 meters. In the study we applied combined formula (Cooper's formula + Howald's formula/ 2) [4], and the effect of this calculation in $\mathrm{ml} / \mathrm{min} / \mathrm{kg}$ became the measure of oxygen consumption for the tested group of pupils.

3. Step-test - allowing the evaluation of endurance abilities. In the research we determined the rhythm of taking steps up and down on platform step in the rhythm determined by methronome. To measure heart rate (HR) sport-testers from Polar company (Finland) were used (model FS2c, Polar Accurex Plus and Polar Xtrainer Plus). On the basis of obtained results we calculated the value of physical fitness index (FI) according to the formula: $\mathrm{FI}=\mathrm{t}^{*} 100 / 5,5^{*} \mathrm{p}$, where $\mathrm{t}$ signifies time of work in seconds and $\mathrm{p}$-heart rate (HR) measured after effort accomplishment [5].

4. Index of Restitution Effectiveness (IRE). Index was calculated according to the formula IRE $=(\mathrm{C} 2-\mathrm{C} 3 / \mathrm{C} 2-\mathrm{C} 1) * 100 \%$, where: $\mathrm{C} 1$ - heart rate in rest, $\mathrm{C} 2$ - heart rate directly after effort accomplishment, C3 heart rate in the third minute after finishing effort [5]. The IRE reflects the level of general endurance; hence, the higher the value, the higher the process of endurance adaptation is. To determine HR we used above mentioned models of Polar sport testers.

Both groups were divided in relation to research factors collected in groups of individual and environmental conditionings of physical fitness, such as experiment's participation, residence and gender.

For all divisions outstanding number of cases we noticed shortage of normal distribution. It was the base to use nonparametric test of statistically significance of differences. To compare experimental and control group we applied U Mann-Whitney test. For all calculations assumed level of statistical significance did not exceed $5 \%$ of random mistake $(\mathrm{p}<0.05)$.

\section{RESULTS}

In 3 physical fitness testes the group practicing in outdoor classes presented better results: speed (run on a distance of 60 meters), jumping abilities (standing long jump) and endurance (run on a distance of 600 meters). In all other tests there were no statistically significant differences $(p>0.05)$, but in total general physical fitness was better among pupils undertaking outdoor classes.

Table I. Grade set of average results from particular tests of International Physical Fitness Test for the experimental and control group during initial and final measurements

\begin{tabular}{|c|c|c|c|}
\hline Test & Group & Initial test & Final test \\
\hline \multirow[t]{3}{*}{ 50-meter sprint } & experimental & 59.5 & 65.6 \\
\hline & control & 59.5 & 60.6 \\
\hline & $\mathrm{p}$ & 0.986 & 0.008 \\
\hline \multirow{3}{*}{$\begin{array}{l}\text { standing long } \\
\text { jump }\end{array}$} & experimental & 59.1 & 64.9 \\
\hline & control & 59.4 & 60.4 \\
\hline & $\mathrm{p}$ & 0.977 & 0.001 \\
\hline \multirow[t]{3}{*}{600 -meter run } & experimental & 57.6 & 68.3 \\
\hline & control & 59.7 & 60.5 \\
\hline & $\mathrm{p}$ & 0.385 & 0.000 \\
\hline \multirow[t]{3}{*}{ grip strength } & experimental & 56.9 & 58.5 \\
\hline & control & 57.4 & 58.3 \\
\hline & $\mathrm{p}$ & 0.929 & 0.801 \\
\hline \multirow[t]{3}{*}{ pull-ups } & experimental & 57.7 & 59.4 \\
\hline & control & 57.3 & 58.2 \\
\hline & $\mathrm{p}$ & 0.662 & 0.372 \\
\hline \multirow{3}{*}{$\begin{array}{l}4 \times 10-\text { meter } \\
\text { shuttle run }\end{array}$} & experimental & 59.4 & 61.0 \\
\hline & control & 57.9 & 58.8 \\
\hline & $\mathrm{p}$ & 0.358 & 0.170 \\
\hline \multirow{3}{*}{$\begin{array}{l}\text { 30-second sit- } \\
\text { ups }\end{array}$} & experimental & 57.7 & 59.4 \\
\hline & control & 59.3 & 60.3 \\
\hline & $\mathrm{p}$ & 0.522 & 0.801 \\
\hline \multirow[t]{3}{*}{ trunkflexion } & experimental & 59.8 & 61.3 \\
\hline & control & 59.3 & 60.1 \\
\hline & $\mathrm{p}$ & 0.589 & 0.394 \\
\hline \multirow[t]{3}{*}{ Total } & experimental & 467.6 & 498.4 \\
\hline & control & 470.1 & 477.2 \\
\hline & $\mathrm{p}$ & 0.807 & 0.014 \\
\hline
\end{tabular}

Participation in outdoor classes showed to be important for shaping physical endurance. In contrast to initial measurement, final one presented statistically significant $(\mathrm{p}<0.05)$ advantage in restitution effectiveness and oxygen consumption comparing to control group (table II). 
Table II. Average results of chosen physical fitness and respiratory capacity indices in the experimental and control group in initial and final measurement

\begin{tabular}{|c|l|c|c|}
\hline Test & \multicolumn{1}{|c|}{ Group } & Initial test & Final test \\
\hline \multirow{3}{*}{$\begin{array}{c}\text { Physical Fitness } \\
\text { Index } \\
(\mathrm{FI})\end{array}$} & experimental & 34.53 & 35.56 \\
\cline { 2 - 4 } & Control & 34.83 & 35.19 \\
\cline { 2 - 4 } & $\mathrm{P}$ & 0.180 & 0.638 \\
\hline \multirow{3}{*}{$\begin{array}{c}\text { Index of Restitution } \\
\text { Effectiveness (IRE) }\end{array}$} & experimental & 67.15 & 72.33 \\
\cline { 2 - 4 } & control & 64.19 & 65.50 \\
\cline { 2 - 4 } & $\mathrm{P}$ & 0.229 & $\mathbf{0 . 0 0 2}$ \\
\hline \multirow{2}{*}{$\mathrm{VO}_{2} \max$} & experimental & 31.08 & 38.85 \\
\cline { 2 - 4 } & control & 31.48 & 36.43 \\
\cline { 2 - 4 } & $\mathrm{P}$ & 0.737 & $\mathbf{0 . 0 0 6}$ \\
\hline
\end{tabular}

Considering sex of pupils (girl vs. boys) we also found 3 statistically significant differences and in each case better results were observed in the male group. In test of standing long jump and pull-ups the advantage was observed both in initial and final measurements. Test of 30-second sit-ups presented the advantage of boys during final measurementonly. Finally in last measurement boys presented better general condition also.

Table III. Average results of International Physical Fitness Test for the group of boys and girls in initial and final measurement

\begin{tabular}{|c|c|c|c|}
\hline Test & Group & Initial test & Final test \\
\hline \multirow[t]{3}{*}{ 50-meter sprint } & Boys & 60.4 & 63.5 \\
\hline & Girls & 58.6 & 61.9 \\
\hline & $\mathrm{P}$ & 0.308 & 0.288 \\
\hline \multirow{3}{*}{$\begin{array}{l}\text { standing } \\
\text { longjump }\end{array}$} & boys & 60.9 & 64.1 \\
\hline & girls & 57.6 & 60.6 \\
\hline & $\mathrm{P}$ & 0.034 & 0.023 \\
\hline \multirow[t]{3}{*}{ 600-meter run } & boys & 59.3 & 65.1 \\
\hline & girls & 58.2 & 62.6 \\
\hline & $\mathrm{P}$ & 0.976 & 0.142 \\
\hline \multirow[t]{3}{*}{ gripstrength } & boys & 57.6 & 58.9 \\
\hline & girls & 56.7 & 57.8 \\
\hline & $\mathrm{P}$ & 0.666 & 0.649 \\
\hline \multirow[t]{3}{*}{ pull-ups } & boys & 60.3 & 61.4 \\
\hline & girls & 54.6 & 56.0 \\
\hline & $\mathrm{P}$ & 0.001 & 0.002 \\
\hline \multirow{3}{*}{$\begin{array}{l}4 \times 10 \text {-meter } \\
\text { shuttle run }\end{array}$} & boys & 59.2 & 60.6 \\
\hline & girls & 57.8 & 58.8 \\
\hline & $\mathrm{P}$ & 0.196 & 0.134 \\
\hline \multirow[t]{3}{*}{30 -second sit-ups } & boys & 59.9 & 61.4 \\
\hline & girls & 57.3 & 58.3 \\
\hline & $\mathrm{P}$ & 0.066 & 0.028 \\
\hline \multirow[t]{3}{*}{ trunkflexion } & boys & 60.1 & 61.3 \\
\hline & girls & 58.8 & 59.9 \\
\hline & $\mathrm{P}$ & 0.487 & 0.403 \\
\hline \multirow[t]{3}{*}{ Total } & boys & 477.8 & 496.3 \\
\hline & girls & 460.3 & 476.0 \\
\hline & $\mathrm{P}$ & 0.053 & 0.028 \\
\hline
\end{tabular}

Boys shown an advantage in all indices of physical fitness and in each case the differences were statistically significant $(\mathrm{p}<0.05)$.
Table IV. Average values of physical fitness and respiratory capacity for group of boys and girls in initial and final measurement

\begin{tabular}{|l|l|c|c|}
\hline Test & \multicolumn{1}{|c|}{ Group } & Initial test & Final test \\
\hline \multirow{5}{*}{ FI } & boys & 35.52 & 36.24 \\
\cline { 2 - 4 } & girls & 33.88 & 34.45 \\
\cline { 2 - 4 } & P & $\mathbf{0 . 0 0 0}$ & $\mathbf{0 . 0 0 0}$ \\
\hline \multirow{4}{*}{ IRE } & boys & 69.80 & 73.68 \\
\cline { 2 - 4 } & girls & 61.04 & 64.21 \\
\cline { 2 - 4 } & P & $\mathbf{0 . 0 0 0}$ & $\mathbf{0 . 0 0 0}$ \\
\hline $\mathrm{VO}_{2}$ max & boys & 33.29 & 39.63 \\
\cline { 2 - 4 } & girls & 29.31 & 35.25 \\
\cline { 2 - 4 } & P & $\mathbf{0 . 0 0 0}$ & $\mathbf{0 . 0 0 0}$ \\
\hline
\end{tabular}

Place of residence was not shown to be the element varying physical fitness of pupils (table V). There were no statistically significant differences between pupils living in urban and rural areas $(\mathrm{p}>0.05)$.

Table V. Average results of International Physical Fitness Test for rural and urban group of pupils in initial and final measurement

\begin{tabular}{|c|c|c|c|}
\hline Test & Group & Initial test & Final test \\
\hline \multirow[t]{3}{*}{ 50-meter sprint } & urban & 58.7 & 61.8 \\
\hline & rural & 60.1 & 63.5 \\
\hline & $\mathrm{p}$ & 0.257 & 0.199 \\
\hline \multirow[t]{3}{*}{ standing longjump } & urban & 59.6 & 62.7 \\
\hline & rural & 59.0 & 62.0 \\
\hline & $\mathrm{P}$ & 0.706 & 0.739 \\
\hline \multirow[t]{3}{*}{ 600-meter run } & urban & 57.7 & 62.5 \\
\hline & rural & 59.7 & 65.0 \\
\hline & $\mathrm{p}$ & 0.090 & 0.053 \\
\hline \multirow[t]{3}{*}{ gripstrength } & urban & 56.7 & 57.9 \\
\hline & rural & 57.5 & 58.8 \\
\hline & $\mathrm{p}$ & 0.351 & 0.358 \\
\hline \multirow[t]{3}{*}{ pull-ups } & urban & 57.8 & 59.1 \\
\hline & rural & 57.2 & 58.4 \\
\hline & $\mathrm{p}$ & 0.468 & 0.525 \\
\hline \multirow{3}{*}{$\begin{array}{l}4 \times 10 \text {-meter } \\
\text { shuttle run }\end{array}$} & urban & 57.8 & 59.2 \\
\hline & rural & 59.1 & 60.2 \\
\hline & $\mathrm{p}$ & 0.135 & 0.219 \\
\hline \multirow[t]{3}{*}{ 30-second sit-ups } & urban & 58.7 & 60.2 \\
\hline & rural & 58.5 & 59.6 \\
\hline & $\mathrm{p}$ & 0.885 & 0.642 \\
\hline \multirow[t]{3}{*}{ trunkflexion } & urban & 59.1 & 60.4 \\
\hline & rural & 59.8 & 60.8 \\
\hline & $\mathrm{p}$ & 0.550 & 0.680 \\
\hline \multirow[t]{3}{*}{ Total } & urban & 466.1 & 483.8 \\
\hline & rural & 471.5 & 488.3 \\
\hline & $\mathrm{p}$ & 0.395 & 0.395 \\
\hline
\end{tabular}

Place of residence was not a significant factor influencing the level of physical endurance (table VI). Differences between pupils from urban and rural areas in restitution effectiveness and oxygen consumption were not statistically significant $(p>0.05)$. 
Table VI. Average results of physical fitness and respiratory capacity in the experimental and control group in initial and final measurement

\begin{tabular}{|l|l|c|c|}
\hline Test & \multicolumn{1}{|c|}{ Group } & Initial test & Final test \\
\hline \multirow{4}{*}{ FI } & urban & 34.62 & 35.29 \\
\cline { 2 - 4 } & rural & 34.77 & 35.39 \\
\cline { 2 - 4 } & p & 0.866 & 0.893 \\
\hline \multirow{3}{*}{ IRE } & urban & 64.95 & 68.76 \\
\cline { 2 - 4 } & rural & 65.86 & 69.14 \\
\cline { 2 - 4 } & p & 0.711 & 0.689 \\
\hline $\mathrm{VO}_{2} \max$ & urban & 3104 & 37.17 \\
\cline { 2 - 4 } & rural & 31.54 & 37.70 \\
\cline { 2 - 4 } & $\mathrm{p}$ & 0.326 & 0.226 \\
\hline
\end{tabular}

\section{DISCUSSION}

Obtained results indicate a positive influence of outdoor lessons of physical education on physical fitness and endurance. Experimental group achieved advantages in final measurement in speed, jumping abilities and endurance. Despite of lack of statistically significant differences in the other elements of physical fitness, the sum of points achieved in all eight tests in final measurement gave significant advantage to the experimental group. In the range of physical endurance, the advantage included oxygen consumption and index of restitution efficiency; however, statistically significant difference was observed for final measurement only.

Okely et al. investigated the effects of an extended outdoor education school program (ESOESP) on aerobic fitness of adolescent males. 51 participants aged 14-15 years completed a pre- and post-test multistage fitness tests (MST). The pre-test was conducted in week one and the post-test was conducted in week sixteen of their ESOESP program. The MST results indicated a significant increase in the predicted $\mathrm{VO}_{2} \max$ scores using a dependent $\mathrm{t}$-test $=12.09$ $(\mathrm{p}<0.05)$ between the pre and post-test. This represents a $14 \%$ increase in $\mathrm{VO}_{2}$ max in adolescent male stores [6].

The purpose of another study from Australia was to investigate the effect of two different 18 -week outdoor physical activity programs, which were conducted simultaneously at two different locations (city and countryside). Authors indicated that outdoor education physical activities at a ESOESP was effective in improving health related fitness in a short term. Four out of five variables (body composition, cardiorespiratory endurance, muscular endurance and muscular strength) were significantly increased at the $\mathrm{p}<0.05$ level, the fifth variable (flexibility) was not significantly increased. Despite these positive changes in health related fitness, authors were unable to clearly indicate a benefit of perceived athletic competence, behavioral conduct, close friendship, global self-worth, scholastic competence and social acceptance after 18 weeks of the experimental outdoor education physical activities intervention. These results indicated that the same program at the city based campus in Sydney was not effective in improving health related fitness in the short term. The results indicated that only two of the five health related fitness variables were significantly improved in urban group (cardiorespiratory endurance and muscular endurance) but results were differentiated [7].

In the Polish study considering elementary school pupils statistical differences of aerobic capacity tests were observed [8]. Outdoor activity group had better results than indoor group.

In another study [8], values of fitness index (FI) were initially at the level of 50 in group of 11 year old girls and decreased to the value of 46 in the following two years. 11 year old boys had initial fitness index higher the girls (54), which slightly increased to 55 in the following two years. Efficiency of restitution index (ERI) was on the level of 39 in group of 11years old girls and 44 in group of 13 years girls. In the group of boys, ERI values were initially at the level of 55, but significantly decreased to 44 in the following two years. In our study we also observed statistically significant advantage of listed above indices of aerobic capacity in group of boys. Still, in comparison to researches of Żurek et al. results of FI for both genders were considerably worse, whereas results of ERI were definitely better.

Observations of outdoor and indoor physical education lessons show that students in indoor lessons spent significantly more time sitting than students in outdoor lessons (29\% vs. $8 \%$ ) and less time standing ( $37 \%$ vs. $49 \%$ ). Boys tended to be more active than girls, primarily due to their greater activity levels during free play opportunities. Overall, boys spent relatively less time standing ( $40 \%$ vs. $44 \%$ of lesson time) [10].

Italian authors state that the enhanced program of physical education lessons was effective in improving physical abilities of 8-11 years old children and determining a decrease (boys: 10\%; girls: 12\%) in daily sedentary activities. The percentages of overweight and obese children did not vary significantly, but the experimental group showed a 
significantly lower rise in BMI compared to the control group $(\mathrm{p}<0.001)$ [11].

American studies related to psychological aspects of physical education lessons showed an improvement in mental well-being. Exercising in natural environments was associated with greater feelings of revitalization, increased energy and positive engagement, together with decreases in tension, confusion, anger and depression [12]. Participants also reported greater enjoyment and satisfaction with outdoor activity and stated that they were more likely to repeat the activity at a later date. It seems that positive psychological changes as a result of contact with nature may be independent of age. In the study of Brodie et al. group of adults who practiced physical activity outdoor formed better opinions about their health when compared to those practicing physical exercise inside buildings [1].

Gender is very important factor which has an influence on peak oxygen intake [13]. Boys tend to show higher levels of physical activity than girls from childhood to senility. Since girls are less active and develop fine motor skills faster, they may have some advantage over boys until school age [14]. For adolescent females (aged 10 to 19) results $\mathrm{VO}_{2} \max$ are between 38 and $46 \mathrm{ml} / \mathrm{kg} \times \mathrm{min}$, and for males that age the values are higher: $47-56 \mathrm{ml} / \mathrm{kg} \mathrm{x} \mathrm{min.} \mathrm{In} \mathrm{France,}$ the satisfactory norms for non-trained children include body mass without an allometric equation (boys: 47 +/2 ml.mn.-1 kg-1, girls: 40 +/- 3 ml.mn.-1 kg-1 with a post puberty decrease) [15]. Therefore, gender-related differences in the presented study are not surprising. The group of boys had larger scores $(33,29 \mathrm{ml} / \mathrm{kg} \mathrm{x}$ $\mathrm{min}$ in initial test and $39,63 \mathrm{ml} / \mathrm{kg} \mathrm{x} \mathrm{min} \mathrm{in} \mathrm{final} \mathrm{study)}$ then the girls $(29,31 \mathrm{ml} / \mathrm{kg} \times \mathrm{min}$ in initial test and $35,25 \mathrm{ml} / \mathrm{kg} \times \mathrm{min}$ after two years). Turkish study demonstrated significant age related differences, too. Boys who were 13 years old had higher oxygen uptake at anaerobic threshold, peak $\mathrm{VO}_{2}$ and exercise test duration than those of girls of the same age $(p<0.05)$ [16].

The purpose of another study was to examine the tracking of field-assessed fitness components in boys and girls from the second to sixth grades [17]. Fitness tests included a 600-m run, a flying-start sprint, the standing long jump, and a medicine ball throw. Additionally, subjects performed a skill task that involved slalom dribbling of basketball. Baseline scores of $2^{\text {nd }}$ school class were correlated with scores attained in $6^{\text {th }}$ school class. Boys had significantly $(\mathrm{p}<$
0.05) better scores in all fitness tests compared with girls in both grades. Achievements of girls were consistently lower than boys', perhaps reflecting their earlier maturation.

The aim of the Spanish study was to determine the effects of Physical Education on body composition and health-related fitness (EUROFIT) among boys and girls aged 8 to 12 years old [18]. Subjects were tested at baseline and at week 20. Girls showed more fat mass than boys $(\mathrm{p}<0.05)$ and boys was more height than girls $(\mathrm{p}<0.05)$. But health-related fitness showed differences by gender only in slalom $(p<0.05)$. The results of body composition and health-related fitness revealed that the physical activity at school is not sufficient to support an ideal level of health-related fitness [18]. Therefore, we should treat seriously the problem in new school interventions in order to achievement better effects of education.Well recognized gender differences aerobic power [19], muscle strength [20] and obesity [21] in primary school children.

The significance of place of residence for biological development has been controversial for a long time. In our study there were no statistically significant differences between urban and rural population. Results of American researches showed higher level of somatic and motor development for children from towns [22], but subsequent analysis did not confirm it. When elementary development of all parameters of boys and girls from both environments were compared, in most cases no statistically significant differences between them were stated. Exception was thinness of skinfolds of rural girls [23]. In other study prevalence of overweight was higher among rural children $(25 \%$; $\mathrm{p}<0.001)$ than children from urban areas (19\%) and small cities (17\%) [24].

The majority of urban-rural differences reports is ambiguous. In one of them the rural children were doing better than urban children in bent-leg curl-ups and standing long jump tests [25]. Last Croatian data says that body mass index and body fat percentage are slightly higher in the urban boys and girls but they do not differ significantly. Urban children perform significantly better in the $20 \mathrm{~m}$ dash, standing long jump and timed sit-ups [26]. The physical fitness of school children of urban and rural area of Mexico was compared as well. Urban children were significantly taller and heavier than rural children. Absolute grip strength did not consistently differ between the rural and urban children, but when adjusted for age and 
body size, strength was greater in rural children. Explosive power (standing long jump) and abdominal strength and endurance (timed sit-ups) were better in urban than in rural children. Younger rural children and older urban girls performed better in the distance run, whereas older rural and urban boys did not differ in endurance [27]. The aim of the last analyzed study was to investigate physical fitness in relation to fatness in urban and rural Greek children by means of allometric scaling. Independent-samples $t$ tests revealed that vertical jump ( $\mathrm{p}<0.05)$ was significantly higher in boys living in urban settings compared to their rural counterparts. Similarly, basketball throw was found to be significantly better $(\mathrm{p}<0.05)$ in urban girls, whereas handgrip strength was significantly higher $(\mathrm{p}<0.05)$ in rural girls [28].

Results of presented above physical exercises capacity tests show lack of differences between urban and rural group. It seems that residence as conditioning of physical fitness and endurance can be considered only in case of significant differences between sanitary condition of atmosphere on urban and rural areas. It is especially related with highly polluted agglomeration, in which physical activity can be accompanied with increased organism's toxicity and as an effect its decreased fitness.

Mexican authors identified 2 critical periods of outdoor exposure in Mexico City children that coincided with significant concentrations of both ozone and particulate matter with diameters less than 10 micrometers (PM10): during school time after 11:00 A.M. and in the after-school outdoor activity period, usually extending from 1:00 P.M. to 6:00 P.M. 31\% of elementary and $61 \%$ of middle school students have physical education classes after 11:00 A.M. Students in Mexico City spend an average of $19.6 \mathrm{hr} / \mathrm{wk}$ outdoors in the after-school period, during which time they are engaged in light to moderate physical activities [29].

\section{CONCLUSIONS}

Results of the conducted experiment indicated positive changes in chosen elements of physical fitness, as well as in total grading of general fitness. Outdoor lessons of Physical Education influenced positively the results of speed, jumping abilities, aerobic capacity and oxygen consumption, and index of restitution efficiency.

Jumping abilities and strength of arm muscle were higher among boys than among girls without external influence of experimental factor. However, outdoor Physical Education lessons caused considerable improvement in strength of abdominal muscles among the boys in comparison with girls.

Place of residence did not influence the level of physical fitness and capacity in initial and final measurements, besides emphasizing the fact of physical fitness limitation by polluted air in the cities.

\section{ACKNOWLEDGMENTS}

The authors would like to thank school administrators and PE teachers for their support and assistance with this project and for their appreciation of the benefits gained from outdoor research.

\section{CONFLICT OF INTEREST}

The authors declare they have no conflict of interest.

\section{REFERENCES}

1. Brodie D., Roberts K., Lamb K. Citysport Challenge. Burlington Press, Cambridge, 1991.

2. Pasek M., Ziółkowski A., Ekologiczny wymiar kultury fizycznej. AWFiS, Gdańsk, 2014.

3. Drabik J. Testowanie sprawności fizycznej u dzieci, młodzieży i dorosłych. AWF, Gdańsk, 1998.

4. Jeannotat $\mathrm{Y}$. Du test de Cooper a la $\mathrm{VO}_{2} \max$. Jeun e Sport 1980; 5: 106-109.

5. Pasek M. Postawy prosomatyczne uczniów jako efekt zajęć $\mathrm{z}$ wychowania fizycznego $\mathrm{w}$ terenie $\mathrm{i} \mathrm{w}$ sali w świetle wybranych uwarunkowań osobniczych i środowiskowych. [Pupils prosomatic attitudes as an effect outdoor and indoor physical education lessons in view of selected individual and environmenetal conditions]. AWFiS, Gdańsk, 2013.

6. Okely A, Gray T, Cotton W. Effects of an extended stay outdoor education program on aerobic fitness. 10th National Outdoor Education Conference. Collaroy Beach, New South Wales, 1997.

7. Jelley S. 2009. The effect of outdoor education and physical education physical activity programmes upon Male adolescents. University of Wollongong Thesis Collection.

8. Pańczyk W. Biologiczno-zdrowotne i wychowawcze efekty lekcji wychowania fizycznego w terenie i w sali. [Biological, health and educational effects of outdoor and indoor physical education lessons]. ODN, Zamość, 1999.

9. Żurek G, Januszewski A, Ignasiak Z. Research of basic physical efficiency status in children from copper district. NowaMedycyna 2000, 12 (108): 49-51.

10. McKenzie TL, Feldman H, Woods SE, Romero KA, 
Dahlstrom V, Stone EJ, Strikmiller PK, Williston JM, Harsha DW. Children's activity levels and lesson context during third-grade physical education. Res Q Exerc Sport 1995; 66 (3): 184-193.

11. Sacchetti R, Ceciliani A, Garulli A, Dallolio L, Beltrami P, Leoni E. Effects of a 2-year school-based intervention of enhanced physical education in the primary school. J School Health 2013; 83 (9): 639-646.

12. Thompson Coon J, Boddy K, Stein K, Whear R, Barton $\mathrm{J}$, Depledge MH. Does participating in physical activity in outdoor natural environments have a greater effect on physical and mental wellbeing than physical activity indoors? A Systematic Review. Environ Sci Technol 2011; 45 (5): 1761-1772.

13. Wilmore JH, Costill DL. Physiology of Sport and Exercise: 3rd Edition. Champaign, IL: Human Kinetics, 2005.

14. Cook JL, Cook G. Child Development: Principles and Perspectives. University of Wisconsin-Whitewater, 2005.

15. Matecki S, Prioux J, Amsallem F, Mercier J, Prefaut C, Ramonatxo M; Groupe EFR pédiatriques de la Société de Physiologie. Maximal oxygen uptake in healthy children: factors of variation and available standards. Rev Mal Respir 2001; 18 (5): 499-506.

16. Gürsel Y, Sonel B, Gök H, Yalçin P. The peak oxygen uptake of healthy Turkish children with reference to age and sex: a pilot study. Turk J Pediatr 2004; 46 (1): 3843.

17. Falk B, Cohen Y, Lustig G, Lander Y, Yaaron M, Ayalon J. Tracking of physical fitness components in boys and girls from the second to sixth grades. Am J Hum Biol 2001; 13 (1): 65-70.

18. Cepero M, López R, Suárez-Llorca C, Andreu-Cabrer E, Francisco Rojas FJ. Fitness test profiles in children aged 8-12 years old in Granada (Spain) Journal of Human Sport and Exercise 2011; 6 (1): 135-145.

19. Shephard RJ, Lavallée H. Enhanced physical education and body fat in the primary school child. Am J Hum Biol 1993b; 5: 697-704.

20. Shephard RJ, Lavallée H. Impact of enhanced physical education in the prepubescent child Trois-Rivières revisited. Ped Exerc Sci 1993a; 5: 177-189.

21. Shephard RJ, Lavallée H. Impact of enhanced physical education on muscle strenth of the prepubescent child. Ped Exerc Sci 1994; 6: 75-87.
22. Renson R, Beunen G, De Witte L, Ostyn M, Simons J, Van Gerven D. The social spectrum of the physical fitness of 12 to 19 year old boys. Kinanthropometry II (International series on sport sciences 9, M. Ostyned). University Park Press, Baltimore 1980: 104-118.

23. Pasek M, Jerzemowski J. Chosen somatic indicators in village and city primary school children exemplified in the Pomeranian Province. Polish Journal of Environmental Studies 2008; 17 (4A): 293-297.

24. Joens-Matre RR, Welk GJ, Calabro MA, Russell DW, Nicklay E, Hensley LD. Rural-urban differences in physical activity, physical fitness and overweight prevalence of children. J Rural Health 2008; 24 (1): 4954.

25. Wang JH, Wu MC, Chang HH. Urban-rural disparity in physical fitness of elementary schoolchildren in Taiwan. Pediatr Int 2013; 55 (3): 346-354.

26. Ujević T, Sporis G, Milanović Z, Pantelić S, Neljak B. Differences between health-related physical fitness profiles of Croatian children in urban and rural areas. Coll Antropol 2013; 37 (1): 75-80.

27. Peña Reyes ME, Tan SK, Malina RM. Urban-rural contrasts in the physical fitness of school children in Oaxaca, Mexico. Am J Hum Biol 2003; 15 (6): 800813.

28. Tsimeas PD, Tsiokanos AL, Koutedakis Y, Tsigilis N, Kellis S. Does living in urban or rural settings affect aspects of physical fitness in children? An allometric approach. Br J Sports Med 2005; 39 (9): 671-674.

29. Villarreal-Calderón A, Acuña H, Villarreal-Calderón J, Garduño M, Henríquez-Roldán CF, CalderónGarcidueñas L, Valencia-Salazar G. Assessment of physical education time and after-school outdoor time in elementary and middle school students in south Mexico City: the dilemma between physical fitness and the adverse health effects of outdoor pollutant exposure. Arch Environ Health. 2002; 57 (5): 450-60.

\author{
Address for correspondence: \\ Marcin Pasek \\ Gdańsk University of Physical Education and Sport \\ ul. Kazimierza Górskiego 1 \\ 80-336 Gdańsk
}

Received: 20.07.2016

Accepted for publication: 12.08 .2016 